\title{
Verrekening van die kragveld van die verbond in die inkleding van die kommunikatiewe driehoeksverhouding tussen teks, hoorder en prediker
}

\author{
Author: \\ Friedrich W. de Wet ${ }^{1}$ \\ Affiliation: \\ ${ }^{1}$ School for Ecclesiastical \\ Studies, Potchefstroom \\ Campus, North-West \\ University, South Africa \\ Correspondence to: \\ Fritz de Wet \\ Email: \\ fritz.dewet@nwu.ac.za \\ Postal Address: \\ PO Box 19120, Noordbrug \\ 2522, South Africa \\ Dates: \\ Received: 15 Mar. 2011 \\ Accepted: 16 May 2011 \\ Published: 14 Sept. 2012 \\ How to cite this article: \\ De Wet, F.W., 2012, \\ 'Verrekening van die \\ kragveld van die verbond \\ in die inkleding van \\ die kommunikatiewe \\ driehoeksverhouding tussen \\ teks, hoorder en prediker', \\ In die Skriflig/In Luce Verbi \\ 46(1), Art. \#47, 9 pages. \\ http://dx.doi.org/10.4102/ \\ ids.v46i1.47
}

C) 2012. The Authors. Licensee: AOSIS OpenJournals. This work is licensed under the Creative Commons Attribution License.
In hierdie artikel word die kommunikatiewe driehoeksverhouding tussen die Bybelse teks, die hoorders en die prediker homileties verken. Die probleemstelling waarmee gewerk word handel oor potensiële versteurings wat kan plaasvind in hierdie driehoeksverhouding wanneer die hoorders en die prediker in hulle menslike beperktheid in verbinding gebring word met die ewige Woord van God soos dit in die Bybelse teks na vore kom. In die loop van die artikel word die volgende aspekte verken: 'n Ideale tipering van die verhouding tussen die teks, hoorders en prediker waarin al drie faktore 'n regmatige plek het; die maniere waarop die kommunikatiewe driehoek in die spanningsveld tussen teks, hoorders en prediker kan skeeftrek; en pneumatologiese verankering van die kommunikatiewe driehoek in die kragveld van die verbondsruimte, waarin Jesus Christus versoenend (integrerend) teenwoordig is. Die gevolgtrekking waartoe gekom word, is dat die prediker in die kragveld van die verbond in staat gestel word om getrou te bly aan die teks (waarin God aan die Woord kom), aan die hoorders (as mededeelgenote in die genade van God sowel as - in missionêre konteks mense wat geroep word om deelgenote in hierdie genade te word) en aan hom- of haarself (as nuwe mens in Christus) sonder dat die verbintenis aan een element in die kommunikatiewe driehoek die verbintenis aan die ander versteur of laat disintegreer.

Reckoning with the force field of the covenant in aligning the communicative triangle between text, listener and preacher. In this article the communicative triangular relationship between the Biblical text, the listeners and the preacher is reflected upon from a homiletic point of view. The problem statement deals with potential distortions in this triangular relationship when the listeners and preacher (in their human finitude) are brought into contact with the eternal Word of God as it proceeds from the Biblical text. In the course of the article the following aspects are considered: An ideal establishment of the relationship between text, listeners and preacher - giving all three factors their due place; an exploration of situations in which the communicative triangle can possibly be distorted in the tension field between text, listeners and preacher; and anchoring the communicative triangle in the force field of the covenant, where Christ's atoning (integrative) presence is felt. It is concluded that the preacher is enabled by Christ's presence in the force field of the covenant to remain faithful to the text (through which God speaks), to the listener (as partakers in the grace of God as well as - in missionary context - people called to became partakers in this grace) and to himself (as a new man in Christ). This faithfulness entails that commitment to one element in the communicative triangle is not disturbed or disintegrated by commitment to the other elements.

\section{Inleiding}

In die reformatoriese visie op die kommunikatiewe gebeure wat tydens prediking plaasvind, word klem geplaas op die werkingskrag van die Woord. Alhoewel prediking op die oog af na die woorde van 'n menslike prediker lyk wat tot menslike hoorders en hul konkrete situasie gerig is, word daar met die geloofsbelydenis gewerk waarvolgens God deur die woorde van die menslike prediker aan die Woord kom (vgl. 1 Pet 4:11). Volgens Cilliers (2009:2-3) word daar in die reformatoriese beskouing 'n sakramentele karakter aan prediking toegeken. Dit mag wel die prediker se woorde wees wat sy of haar mond tydens die prediking verlaat, maar op weg na die ore van die hoorders verander die Gees die prediker se woorde in die woorde van Christus - in die lewende Woord sélf. Deur die prediker se woorde kom die Verlossingswoord aan die woord; prediking is dan 'n woord waarin en waardeur Christus self die vrugte van sy verlossingswerk uitdeel. Die Woord doen volgens die reformatoriese belydenis immers altyd wat dit sê, bring tot stand wat dit onder woorde bring. Daarom word daar met die geloofsbelydenis gewerk dat die verkondiging van die Bybelse teks nie bloot informatief is nie, maar inderdaad ook performatief. 
J.M. Vorster (2010:449) wat deur sy akademiese werk 'n uitsonderlike bydrae gelewer het tot die verstaan van die rol en impak van reformatoriese denke in die kontemporêre Suid-Afrikaanse samelewing, beklemtoon die rol van prediking in die vernuwing van die samelewing. In die uitvoer van die kerk se roeping om 'n evangeliserende gemeenskap te wees en versoening te bedien in die omliggende samelewing, speel prediking 'n kardinale rol. Deur prediking word versoening as die werk van die drie-enige God bedien. Deur prediking van die Woord van God kom die outentisiteit van die Christelike gemeenskap na vore in die sin dat dit duidelik word dat menslike morele aksie in die samelewing voortvloei uit die werking van Goddelike, reddende genade. Verandering word deur God bewerk deur die prediking van die Woord.

Hierdie artikel fokus op die problematiek rondom die vraag of daar - in ' $n$ ruimte waarin daar sprake is van die performatiewe krag van die ewige Goddelike Woord in en deur die handelinge van die begrensde menslike prediker en hoorders - nie rekening gehou sal moet word met potensiële versteurings en skeeftrekkinge in sodanige kommunikatiewe proses nie? Verskeie verskynsels beklemtoon die noodsaak daarvan om die kommunikatiewe driehoeksverhouding tussen teks, hoorders en prediker grondig te verken. Dit sluit in die optrede van predikers wat (in frustrasie dat daar skynbaar niks gebeur nie) 'n woord spreek waardeur hulle dinge self wil laat gebeur in die kerk en aanpassing van die gerigtheid van die Woord om by die eie menslike agenda van die prediker (en die hoorders) in te val (vgl. De Wet \& Kruger 2010:411)

In hierdie artikel word die spanningsveld of kragveld van die kommunikatiewe driehoek tussen die Bybelse teks (waarin God aan die Woord kom), die hoorders en die prediker met 'n gereformeerde benaderingswyse vanuit die volgende invalshoeke verken:

- Die ideale tipering van die verhouding tussen die teks, hoorders en prediker as 'n kommunikatiewe driehoek waarin al drie faktore 'n regmatige plek het.

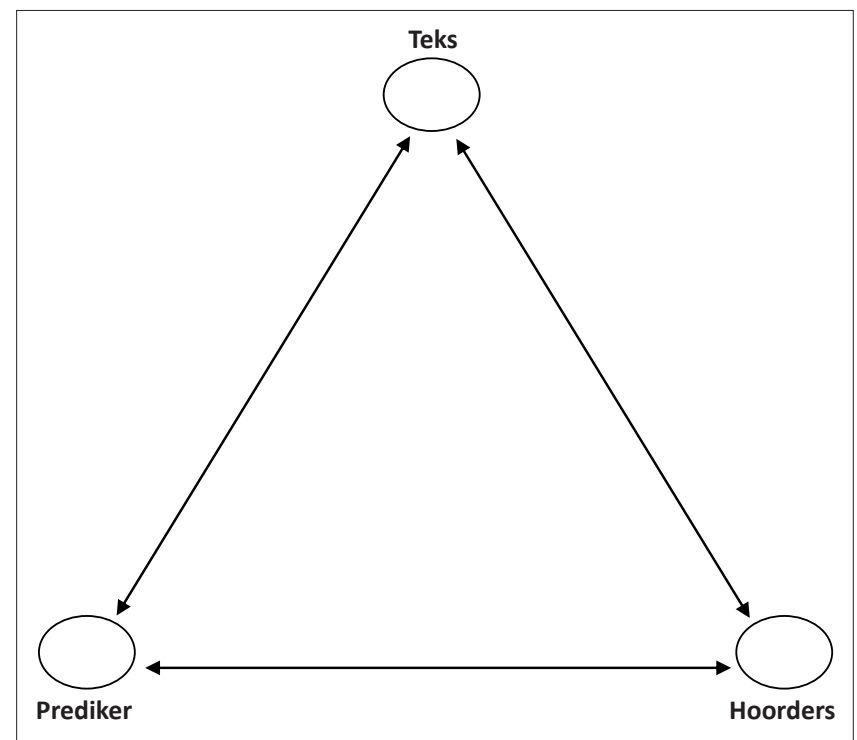

FIGUUR 1: Die kommunikatiewe driehoek tussen teks, prediker en hoorders.
- Maniere waarop die kommunikatiewe driehoek in die spanningsveld tussen teks, hoorders en prediker kan skeeftrek.

- Pneumatologiese verankering van die kommunikatiewe driehoek in die kragveld van die verbondsruimte, waarin Jesus Christus, die Gekruisigde en opgestane Here, versoenend (integrerend) teenwoordig is.

Deur hierdie verkenning word gepoog om 'n bydrae te lewer tot teologiese meningvorming op die gebied van Homiletiek.

\section{Die ideale tipering van die verhouding tussen die teks, hoorders en prediker as 'n kommunikatiewe driehoek waarin al drie faktore 'n regmatige plek het}

In aansluiting by kommunikatiewe teorieë waarvan in sosiale en psigologiese wetenskappe gebruik gemaak word, word die verhouding tussen teks, hoorders en prediker in homiletiese literatuur dikwels as 'n kommunikatiewe driehoek uitgebeeld (Brueggemann 2005:495, 2010:43; Monshau 2006:152; Tisdale 2010:49; vgl. Andriessen \& Miethner 1993:253; Van Leeuwen \& Struijs 2008:147).

Bowen (1978) werk in sy teorie rakende gesinsterapie met die konsep van 'triangling'. Hiervolgens word kommunikatiewe netwerke in die gesinsopset verklaar as ' $n$ reeks driehoeksverhoudinge wat na vore kom in ' $n$ netwerk van verhoudinge met oneindige herhalingspatrone van 'twee teen een'. Die doel van gesinsterapie is dan om ongesonde driehoeksverhoudinge (waarin twee persone altyd teen 'n derde saamsmee in die beoefening van 'n manipulerende magspel) op te breek ten einde oop en gesonde verhoudingsnetwerke tot stand te bring (vgl. Guerin 1996:49).

In 'n ideale kommunikatiewe omgewing sou die driehoek tussen die teks (waarin God aan die Woord kom), hoorders en prediker op 'n gesonde manier kon funksioneer. In 'n ideale omgewing werk die Woord van God so in en deur die prediker en die hoorders dat die Woord nie gekaap word vir die bevordering van die prediker se eie agenda nie, of sal dit nie 'skadeloos' oor die koppe van die hoorders trek nie. In 'n ideale kommunikatiewe situasie kan hierdie verhoudingsnetwerk as 'n driehoek uitgebeeld word waarin die drie hoeke op 'n ewewigtige wyse in lewende kontak aan mekaar verbind word (kyk Figuur 1).

In 'n ideale inkleding van hierdie kommunikatiewe driehoeksverhouding behoort na my oordeel die volgende aspekte teenwoordig te wees:

- Al drie verbindingspunte behoort 'n regmatige en volle plek in die homiletiese ruimte te beklee; 'n regmatige plek wat deur God in sy wysheid en goedheid daaraan gegee word. Daar kan nie sprake wees van 'n verhouding tussen slegs twee verbindingspunte, terwyl die derde op die agtergrond verdwyn en tot ' $n$ mindere mate in ag geneem word nie. 
- In 'n ideale kommunikatiewe driehoek behoort daar van nabyheid sowel as afstand sprake te wees. Hoewel die verbindingspunte in lewende kontak aan mekaar verbind is, word hulle tog van mekaar onderskei en gaan die een nie in die ander op nie of span twee nie saam sodat die derde verbindingspunt in afstandelikheid geïsoleer word nie.

- Daar behoort ' $n$ bepaalde orde bespeurbaar te wees in die manier waarop die kommunikatiewe verhouding tussen die drie verbindingspunte tot uitdrukking gebring word. Op die boonste punt van die driehoek word die teks (waarin God aan die Woord kom) gevisualiseer. Op die onderste twee punte staan onderskeidelik die hoorders en die prediker.

- Een verbindingspunt behoort gelyktydig voluit aan die ander twee punte verbind te wees.

Hierdie aspekte word nou kortliks agtereenvolgens bespreek.

\section{Die regmatige en volle plek van die teks, die hoorders en die prediker in die kommunikatiewe driehoek}

In die kommunikatiewe ruimte wat tydens die homiletiese proses ter sprake kom, moet aan die Bybelse teks 'n regmatige en volle plek gegee word. Die teks moet toegelaat word om volgens die aard daarvan voluit dit te wees wat God daarmee beoog. Die Bybelse teks waarmee gewerk word tydens die homiletiese proses, vorm deel van die opskrifgestelde Woord van God wat deur die Gees geïnspireer is (2 Tim 3:16). Deur die Woord word die blye klank van die evangelie van die gekruisigde en opgestane Jesus Christus openbarend gebring sodat waar daar duisternis is, lig kan skyn en waar daar dood is, ewige lewe kan deurbreek (Joh 3:16). Die Woord van God sny soos 'n swaard in die diepste gedagtes in en bring daar onderskeid en insig mee (vgl. Heb 4:12). Alle dinge lê oop en ontbloot voor die oë van Hom voor wie ons rekenskap moet doen (Heb 4:13; vgl. Bakker 2007:33).

In die kommunikatiewe ruimte van die homiletiese proses moet daar ook aan die hoorders ' $n$ volle en regmatige plek gegee word. Die evangelie het 'n konkrete adres- en kontakpunt waardeur die Here die vernuwende krag van sy koninkryk in hierdie wêreld laat deurbreek. As mense vir wie die lidmaatskap van die liggaam van Christus toeganklik gemaak word, word die hoorders geroep en deur die Woord toegerus om God se heiligheid sigbaar te maak en die liefde van Christus konkreet en genesend te bedien in 'n wêreld wat daarvoor bestem is om bevry te word van verskeurende en korrupterende kragte (2 Kor 5:19; 1 Pet 2:9; Matt 5:13-16). Die Woord moet dus tydens prediking teen presies die regte invalshoek gerig word op die werklike omstandighede waarin die hoorders verkeer sodat dit wat hulle die nodigste het om te hoor - ter wille van die uitvoer van hulle roeping - tot hulle kan kom.

Maar ook aan die prediker moet daar in die kommunikatiewe ruimte van die homiletiese proses 'n volle en regmatige plek gegee word. In sy wysheid laat God juis 'n mens wat ook in die konkrete lewensomstandighede en werklikheid van menswees geanker is, tot sy medemense kom. Die prediker kom na sy medemense met 'n kenmerkende, blye stap wat daarvan getuig dat sy voete nie deur die lood van besorgdheid en vermoeienis, wat so kenmerkend van hierdie bestaan is, neergetrek word nie (vgl. Rom 10:15). Deur middel van 'n medemens, wie se woorde en blye lewensstap getuig van die verlossende krag wat in die evangelie van die gekruisigde en opgestane Here teenwoordig is, word 'n nuwe manier van kyk na die bestaan waarin ons lewens ingebed is, oopgemaak. Deur die blye klanke wat uit die mond van 'n medemens kom, kan die geloofsoë oopgemaak word om die wêreld in 'n hele nuwe lig te sien - in die lig van God se reddende nabyheid.

Nie alleen die teks nie, maar ook die hoorders en die prediker behoort dus 'n regmatige plek te kry in die kommunikatiewe driehoek waarvan daar sprake is tydens die homiletiese proses. Daarom is Douma (2000:60) se raad aan die homileet: Bly by die teks; bly by die hoorder; bly by jouself.

\section{Nabyheid en afstand}

Die kommunikatiewe verhouding tussen teks, hoorders en prediker word 'oopgetrek' in 'n ruimte waarin die drie verbindingspunte in 'n driehoekvorm van mekaar onderskei word en dus nie in mekaar opgaan nie. Die homiletiese proses verkeer in 'n spanningsveld waarin daar kragte aan die werk is wat ' $n$ afstand oopmaak tussen onderskeidelik teks en hoorders, teks en prediker en hoorders en prediker. Daar is egter ook tegelykertyd aantrekkende en oorbruggende kragte aan die werk wat (in 'n ideale inkleding van die driehoeksverhouding) 'n balans tussen afstand en nabyheid te weeg bring.

Daar is ook sprake van afstandelikheid tussen die teks en die hoorders. Nie alleen van afstandelikheid in die sin dat die teks oorspronklik gerig is op lesers wat 2000 jaar en langer terug geleef het nie, maar ook van afstandelikheid in die sin dat die hoorders weens hul sondige natuur weerstand kan bied teen die volle implikasies van die teks.

Gadamer (1979) wys daarop dat daar in die hermeneutiese verhouding tussen die leser en die teks van 'n konstante worsteling tussen afstand en nabyheid, vervreemding en deelname sprake is (vgl. Pieterse 2010:3). Deur die element van afstandelikheid word faktore van diskontinuïteit tussen teks en hoorders beklemtoon. Die leefwêreld van die oorspronklike lesers van die teks verskil in baie opsigte van die kontemporêre hoorders en die kultuur waarin hulle lewens ingebed is.

Daar is egter tegelykertyd ook van nabyheid en kontinuïteit tussen die teks en die hoorders sprake. Runia (1983:81 ev.) vind in sy hermeneutiese besinning oor die verhouding tussen die teks in die oorspronklike konteks daarvan en die konteks van die hedendaagse hoorders aansluiting by die hermeneutiek van Frör. Laasgenoemde beklemtoon aan die een kant die uniekheid van die situasie waarin die hedendaagse hoorders verkeer, maar wys aan die ander 
kant daarop dat die geestelike situasie van gelowiges op hulle pelgrimstog deur al die eeue dieselfde bly. Die geestelike situasie waarin die kerk hom op sy pelgrimstog bevind bevat elemente van kontinuiteit met die vorige geslagte van gelowiges terug tot in die Bybelse tyd. Die 'einmaligkeit' van die gemeente se situasie word deur die feit dat dit tegelykertyd ook nie 'erstmalig' is nie, in 'n konteks geplaas waarin 'n 'Brückenschlag' moontlik is (Frör 1961:252). Sodoende kan die teks en die hedendaagse situasie op 'n lewende wyse in verbinding met mekaar gebring word.

Daarom moet rekening gehou word met faktore van kontinuïteit waardeur die kloof tussen teks en hoorders oorbrug kan word. Hedendaagse hoorders se lewens word in hulle ontstaan, voortbestaan en voleinding geanker in die geloof in die Skepper, Verlosser en Voleindiger soos dit met die oorspronklike lesers van die teks ook die geval was. Hetsy dit deur middel van individualisme of pluralisme, relativisme, skeptisisme en hedonisme is, waardeur die element van diskontinuïteit in die moderne kultuur na vore kom (vgl. Vos 1995:4), is dit die Drie-enige God alleen wat diskontinuïteit kan oorbrug deur sy lewende teenwoordigheid. Sy teenwoordigheid is gister en vandag en tot in ewigheid dieselfde.

Die verbond met sy kenmerkende indikatief-, imperatiefen beloftestruktuur bly vir die eietydse hoorders steeds die kenmerkende ruimte waarin die verhouding met God gegiet word en waardeur hulle van koersloosheid teruggeroep word en in God geanker word. Dit was met die oorspronklike lesers van die teks ook die geval (vgl. Coetzee 1985:18). (Die verbondstruktuur en die kragveld waarin dit die kommunikatiewe driehoek tussen teks, hoorders en prediker plaas, word breedvoering onder die voorlaaste hoofpunt van hierdie artikel bespreek waarin die kommunikatiewe driehoek pneumatologies veranker word in die verbondsruimte waarin Jesus Christus versoenend teenwoordig is).

Dieselfde spanningsveld tussen afstandelikheid en nabyheid kom ook ter sprake in die verhouding tussen die teks en die prediker. Aan die een kant staan die prediker met die besef dat hy as sondige, gebroke en begrensde mens nie in staat is om die heilige, volmaakte en ewige Woord van God in die volle omvang daarvan te bring nie. Maar aan die ander kant word hy omvou deur die genade van God wat hom roep en bekwaam maak vir sy diens. Die verhouding tussen die prediker en die teks is ' $n$ verhouding waarin die prediker nie maklik en sonder inspanning tot die volle betekenisdraagwydte van die teks kom nie. Die prediker kom voortdurend tot die besef dat sy aanvanklike verwagtinge ten opsigte van die teks en die betekenis daarvan vir die hoorders ontoereikend is. Sy aanvanklike visie word deur eie vooroordele en begrensdheid ingeperk. Dit is deur intensiewe worsteling in gebed, gedeë eksegese en bepeinsing heen dat die rykdom van die teks deur die genade van God oopgemaak word. Daar kan geen groter vreugde vir die prediker wees as dit wat beleef word wanneer die rykdom van die teks vir hom oopgemaak word nie.
Wat die verhouding tussen die prediker en die hoorders aanbetref, is medemenslikheid die gemeenskaplike en samebindende faktor. Die prediker is saam met die hoorders ingebed in dieselfde menslike bestaan. As iemand wat voluit deelagtig is aan die vlees- en bloedbestaan verkeer hy in dieselfde toestand van kwesbaarheid en aanvegtinge as die hoorders. As hoorder onder die hoorders het hy die boodskap van die evangelie net so nodig soos sy medemense (Heb 2:14-15; Dingemans 1991).

Maar daar is ook ' $n$ aspek wat die prediker van die hoorders onderskei en gevolglik 'n (gesonde) afstand tussen hierdie twee onderste verbindingspunte in die homiletiese kommunikatiewe driehoek ooptrek, naamlik die besondere diens waartoe die prediker geroep is en waarvoor Hy deur die gawes wat die Gees gee, toegerus is. Hy is geroep om die Woord in diens van Christus te bedien. Hy bedien die koninklike gesag van Christus, sodat sy woorde en geloofsvoorbeeld - in die mate waarin dit die merktekens van die Koning van die kerk dra - deur die hoorders met ontsag ontvang word (vgl. Heb 13:7). Wanneer hoorders in die geloof die merktekens van suiwere Woordverkondiging sien kan hulle prediking nie bloot as menslike woorde ontvang nie, maar as die woorde van iemand deur wie God aan die woord kom (1 Pet 4:11) - 'n woord wat oproep tot geloofsgehoorsaamheid (vgl. Heymel 2006:42).

\section{'n Bepaalde orde}

In die kommunikatiewe driehoek wat in die homiletiese proses ter sprake kom, word die teks op die boonste verbindingspunt gevisualiseer en die hoorders en die prediker op die onderste twee verbindingspunte. Deur hierdie voorstelling word veronderstel dat daar van 'n bepaalde orde in die kommunikatiewe gebeure tydens die homiletiese proses sprake is. Die hoorders en prediker verkeer in die kommunikatiewe verhouding met die teks nie op dieselfde vlak as die teks nie. Die trialoog tussen teks, hoorders en prediker vind nie met die veronderstelling plaas dat die teks op gelyke voet met die hoorders en prediker staan of dat die vertrekpunt vir die rigting waarin die gesprek gestuur word by die prediker of die hoorders kan lê nie. Die hoorders en die prediker verkeer in ' $n$ nederige en afhanklike posisie ten opsigte van die teks.

Deur die teks te visualiseer in die boonste verbindingspunt van die kommunikatiewe driehoek, word daardeur tot uitdrukking gebring dat die teks (juis omdat die Woord van God daarin na vore kom) verteenwoordigend is van die vertrekpunt, ontsluitingspunt en voleindigingspunt van die homiletiese gebeure. Die homiletiese proses is ' $n$ Woordbepaalde proses. God maak in sy Woord 'n openbarende perspektief oor sy verbintenis met ons menslike lewe en die wêreld waarin ons lewe oop; 'n perspektief ver bo dit wat ons ooit sou kon dink of antisipeer (vgl. Lischer 2002:40).

God se openbaring word nie alleen vir ons oopgemaak nie, maar ons harte word ook deur Hom ontsluit om ontvanklik vir die Woord te wees. God word in die Skrif die 'hartekenner' 
genoem (ho kardiognôstes theos, Hand 15:8). Hy weet dat ons harte van nature geslote is. Lidia kon wel 'n 'toehoorder' wees, maar kon sonder die werking van God geen innerlike aandag gee aan die ingrypende implikasies van die woorde wat deur Paulus tot haar gekom het nie. Dit is alleen die Here wat haar hart ontvanklik kon maak (Hand 16:14). Uit haarself sou sy nie blywend oor die evangelie van die kruis nadink nie. Dat Jesus as misdadiger gedood is en tog as Heiland leef, is in die oë van 'n mens wie se hart in hierdie wêreld alleen geanker is, absurd en niks anders as dwaasheid nie (vgl. 1 Kor 1:21; Bakker 2007:32).

Brueggemann (2005) beskou die teks met goeie reg as 'the lone member of the triangle':

I believe that the textual conversation in the church could be very different if pastors were able to begin with the awareness that the text is too offensive for the people, but it is also too offensive for the pastor, because it is the living Word of God, and it pushes always beyond where we want to go or be. Such a posture honours the great authority of the text. (p. 496)

Die teks kan dus nie gemanipuleer word en in ons begrensde denkwêreld ingetrek word asof dit op dieselfde vlak as die prediker en die hoorders verkeer nie (vgl. Brueggemann 2010:44).

\section{Een verbindingspunt is gelyktydig aan beide die ander verbind}

'n Verdere kenmerk van die kommunikatiewe driehoekverhouding waarin die teks, hoorders en prediker staan, is dat een verbindingspunt gelyktydig aan beide die ander verbind is. Om slegs op een verbindingslyn tussen twee punte te fokus - sonder om gelyktydig ook die ander verbindingslyn na die derde punt te verreken - sou op 'n verskraling en vereensydiging van die kommunikatiewe gang neerkom. Wanneer die prediker byvoorbeeld slegs 'n verbindingslyn tussen die teks en die hoorders trek, sonder om tegelykertyd daarmee saam ' $n$ verbindingslyn tussen die teks en homself te trek, sou hy die indruk kon skep dat hyself verhewe is bo die kritiese implikasies van die Woord wat op die hoorders gerig word. Wanneer die prediker andersyds slegs ' $n$ verbindingslyn tussen die teks en homself trek, kan hy uitsluitlik konsentreer op die implikasies van die teks vir sy eie omstandighede en voorkeur gee aan sy eie lieflingtemas. Hy kan dan vanuit die invalshoek van die hoorders beleef word as iemand wat ' $n$ monoloog in sy eie droomwêreld voer.

Stott (1992) lewer'n pleidooi vir'n dubbele luister-handeling:

I am not suggesting that we should listen to God and to our fellow human beings in the same way or with the same degree of deference. We listen to the Word with humble reverence, anxious to understand it, and resolved to believe what we come to understand. We listen to the world with critical alertness, anxious to understand it too, and resolved not necessarily to believe and obey it, but to sympathize with it and seek grace to discover how the gospel relates to it. (p. 28)

Dit wat Stott sê rakende die luisterende ingesteldheid van die Christen in 'n dubbele gerigtheid op die Woord en die wêreld, kan toegepas word op die dubbele gerigtheid van die prediker op die teks en die hoorders. Alhoewel die gerigtheid op onderskeidelik die teks en die hoorders in sekere opsigte verskil, beteken dit nie dat daar met minder intensiteit en gefokusde aandag na die hoorders as na die teks geluister word nie.

Daar is verskille in die manier waarop onderskeidelik na die teks en die hoorders geluister word. Daar word na die Woord geluister met nederige eerbied en met die ernstige voorneme om onvoorwaardelik te glo wat daarin geopenbaar word. Die Woord het gesag. Alles wat die hoorders nodig het om te hoor is reeds daarin opgesluit. Daar word met ' $n$ ander gerigtheid na die hoorders geluister. Daar word met kritiese aandag en bewoënheid na die hoorders geluister om presies te bepaal hoe hulle dink, hoe hulle redeneer, wat hulle gesindheid is, wat die hart van die problematiek is waarmee hulle worstel. Die doel van die hierdie luisterhandeling is om die presiese invalshoek te bepaal waarvolgens die Woord met die gesagvolle boodskap daarvan in hierdie situasie ingesny behoort te word.

Maar al is daar verskille in die gerigtheid waarmee na die teks en die hoorder geluister word, beteken dit vir geen oomblik dat daar met minder intensiteit na die hoorders geluister word en die kommunikatiewe verbindingslyn tussen prediker en hoorder op die agtergrond vervaag of losgemaak word van die verbindingslyn tussen prediker en teks nie. Met dieselfde intensiteit waarmee in nederige eerbied na die Woord in die teks geluister word, word met kritiese skerpte en innige besorgdheid na die hoorders geluister. Met dieselfde intense verlange en besorgheid waarmee luisterend gesmag word dat die volle, betekenisryke klank van die Woord gehoor sal word, word ook daarna gesmag dat die ware nood van die hoorders verstaan sal word. Net soos toegang tot die betekenis van die teks nie vanselfsprekend is nie, is ' $n$ fyn begrip en aanvoeling van wat die hoorders nodig het om te hoor ook nie vanselfsprekend nie.

\section{Maniere waarop die kommunikatiewe driehoek in die spanningsveld tussen teks, hoorders en prediker kan skeeftrek}

Weens die beperktheid van die menslike element in die driehoekverhouding (begrensde denke en sondige voorkeure van die prediker en hoorders teenoor die ewigheid en heiligheid van die goddelike Woord) kan verwag word dat die verhouding tussen teks, hoorders en prediker nie altyd in 'n ideale kommunikatiewe omgewing voltrek sal word nie.

Douma (2000:60) identifiseer drie maniere waarop die driesydige homiletiese kommunikasie -vanuit die invalshoek waarmee die homileet betrokke is by die proses - kan skeeftrek:

- Die prediker kan hom eensydig rig op die teks en sy hele homiletiese fokus laat opgaan in verantwoordelike eksegese en interessanthede wat (miskien) daaruit mag voortvloei. 
- Die prediker kan hom eensydig uitlewer aan die hoorder en laasgenoemde se verwagtinge en manier van dink en lewe sentraal laat staan in die preek.

- Die prediker kan hom eensydig uitlewer aan homself. Sy eie geloofsbelewing, sy eie insigte en die invalshoek waarmee hy werk, word dan as onaantasbaar beskou.

Wanneer die prediker hom nie deur die Gees van Christus laat lei nie, maar deur sy eie sondige natuur (vgl. Rom $8: 5)$, word die harmonie in die kommunikatiewe driehoek versteur. Ongesonde elemente soos beskerming van eiebelang en pogings om die effektiewe werkingskrag van die Woordgebeure in die eie hande te neem, tree in die spanningsveld tussen teks, hoorders en prediker in en het ' $n$ disintegrerende en skeeftrekkende uitwerking. Drie maniere waarop die spanningsveld tussen teks, hoorders en prediker (vanuit die invalshoek van die prediker) kan skeeftrek, word nou bespreek, naamlik:

- fiksasie op die teks

- fiksasie op die hoorder

- fiksasie op die prediker.

\section{Fiksasie op die teks}

Wanneer die prediker op die teks fikseer, kan die kommunikatiewe driehoek in die homiletiese proses soos volg disintegreer (kyk Figuur 2).

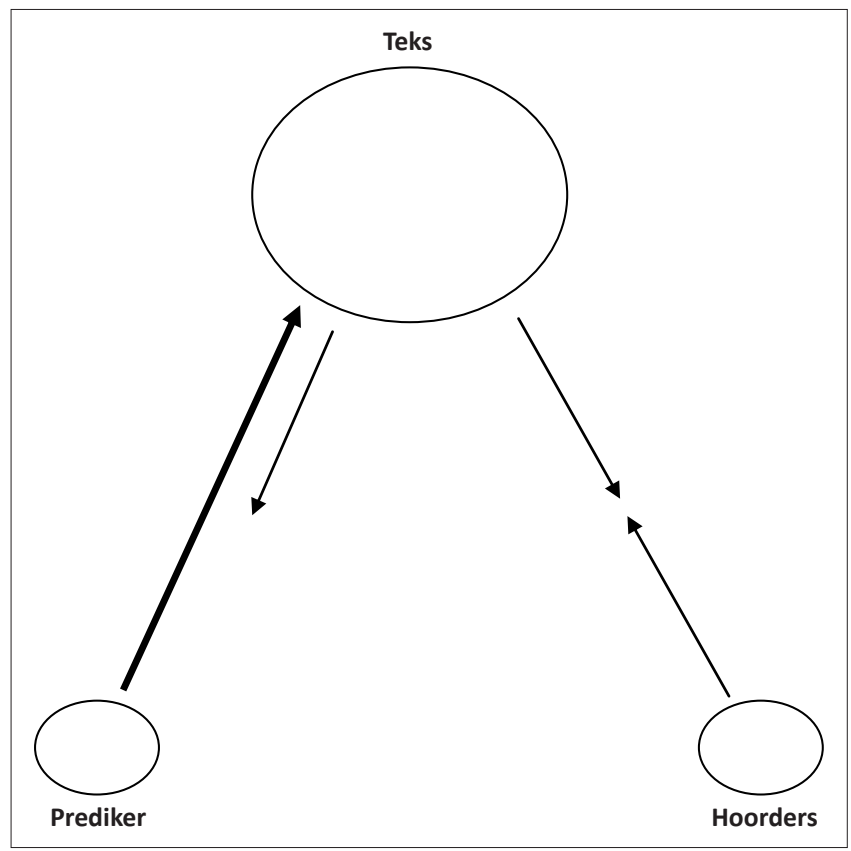

FIGUUR 2: Distorsie ten opsigte van die kommunikatiewe rol van die teks.

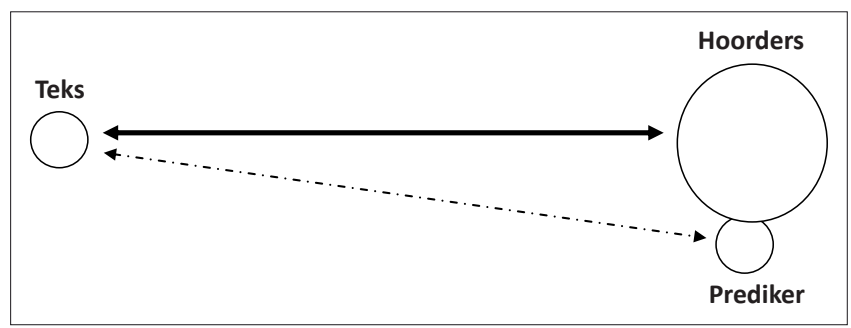

FIGUUR 3: Distorsie ten opsigte van die kommunikatiewe rol van die hoorders.
In bostaande visuele voorstelling is die volgende sake opvallend. In die gerigtheid van die prediker op die teks groei die waarde van kundig besig wees met die teks in die prediker se bewussyn tot buitengewone proporsies. Die prediker raak gefikseer op die teks omdat dit in sy oё 'n verhewe plek het. Hy het die reg om die heilige grond van die teks te betree omdat sy deeglike skoling in die kuns van eksegese hom die nodige kundigheid gee. Die teks is heilig en die onaantasbaarheid daarvan moet ten alle koste beskerm word. Daar mag niks daarvan weggeneem word of bygevoeg word nie. Daar word sterk op die struktuur van die teks en die oorspronklike betekenis daarvan gefokus. Deur versigtige en kliniese eksegese moet die struktuur van die teks verken word en die letterlike en historiese betekenis daarvan intak gehou word. Ook die eenheid van die teks moet gehandhaaf word deur die openbaringshistoriese lyne tussen verskillende tekste en tussen Ou en Nuwe Testamentiese gedeeltes te trek. Goeie eksegese is alles. Wanneer goeie eksegese gedoen is, is 'n goeie preek gewaarborg. Omdat die fokus op die kundige analise van die letter van die teks en die verlede van die teks vasgenael is, is daar nie ruimte om ook in kontak met die God van die Woord - wat hier en nou lewend teenwoordig is - te kom nie.

Die gevolg van hierdie fiksasie op die letter van die teks, is dat die implikasies van die teks vir die prediker en hoorder in die lug bly hang in die vorm van algemene toepassings en gestolde waarhede. Die hoorders neem wel kennis van ' $n$ suiwer waarheid, maar dit vat nie grond in hulle konkrete leefwêreld nie. In hierdie benadering kry die teks alle klem, en word die eie konteks nie as 'n element in die verstaan van die teks met die oog op die preek verreken nie (vgl. Pieterse 2010:2; Lischer 2002:10).

Die worstelinge van prediker en hoorder word nie op 'n aktiewe wyse in die prediking ter sprake gebring nie, omdat dit - na die oordeel van die prediker - kontaminerend kan werk en kan veroorsaak dat menslike gedagtes in die teks ingelees kan word. Dit is ook opvallend dat die verhouding tussen prediker en hoorders gedisintegreer het in die bostaande visuele voorstelling. Die prediker is nie daarop ingestel om na die hoorders te luister nie, maar bedien slegs vanaf 'n afstand 'n boodskap wat op hulle toegepas word.

\section{Fiksasie op die hoorders}

Wanneer die prediker op die hoorders gefikseer is, kan die kommunikatiewe driehoek in die homiletiese proses soos volg skeeftrek (kyk Figuur 3).

Die kommunikatiewe struktuur in die bostaande visuele voorstelling kan soos volg verduidelik word. Die prediker word so in die wêreld van die hoorder ingetrek, dat hy daarop gefikseer raak om aanklank by die hoorders te vind. Die realiteite waarmee die hoorders te doen kry in hulle leefwêreld en die volle impak wat dit op hulle menswees maak, staan in die kollig (Lischer 2002:46). Dit word allerbelangrik dat die boodskap nie so ingerig word dat dit goedkoop en oorvereenvoudigde antwoorde verskaf of 'onnodige beroeringe' onder die hoorders bring nie (vgl. Tisdale 2010:15). 
Die prediker beskou hom- of haarself as iemand wat die interaktiewe dialoog tussen hoorders en teks moet fasiliteer. Hy of sy begin by die vrae en worstelinge van mense en volg ' $n$ induktiewe metode waarin na moontlike ankers vir die hoorders gesoek kan word om stelselmatig in interaksie met die Woord meer lig en duidelikheid op hulle situasie te verkry. Die prediker is sensitief daarvoor om nie vooraf vervaardigde antwoorde aan die hoorders op te dis nie. Daarom word die kommunikatiewe lyn tussen teks en prediker in die bostaande skets by wyse van 'n stippellyn aangedui. Die prediker is sensitief daarvoor om aan elke mens die tyd en ruimte en vryheid te gee om komplekse sake in sy ofhaar lewe in selfstandige omgaan met die teks te verwerk. Hierdie manier van omgaan met die teks kan daartoe aanleiding gee dat slegs 'n relatiewe betekenis aan die teks toegeskryf word. Dit kan verskillende dinge vir verskillende mense beteken.

In die visuele voorstelling word geillustreer hoe teks en hoorders vir alle praktiese doeleindes op dieselfde vlak geplaas word. Die eie perspektief bied net so'n lewensgetroue en egte horison vir oriëntering ten opsigte van die werklikheid waarin die hoorder ingebed is, as nuwe perspektiewe wat in interaksie met die teks kan oopgaan. In hierdie benadering word deeglik rekening gehou met die rol wat menslike vooroordele in die verstaansproses speel. Die rasionaal van ' $n$ hermeneutiese benadering wat die teenwoordigheid van vooroordele volledig wil verreken, verloop soos volg: Eers as ons ons eie situasie met sy bepaalde denke, sieninge en probleme goed bedink het, en dit helder in die bewussyn sit, kan ons na die teks gaan, waar kritiese konfrontasie in die verstaansproses plaasvind. Die gevolg daarvan (as dit goed verloop) is gewoonlik nuwe insigte vanuit die teks en 'n nuwe blik op die eie konteks (vgl. Pieterse 2010:4). Wanneer die verhouding tussen teks en hoorder op hierdie manier ingerig word (met as vertrekpunt die hoorders se vooroordele), is daar egter geen waarborg dat die betekenisdraagwydte van die teks nie verskraal word deur die prominente plek wat aan die hoorders se eie oordeel gegee word nie.

\section{Fiksasie op die persoon van die prediker}

Wanneer die prediker (onbewustelik) in die kompleksiteit van sy eie persoonlike omgewing en persoonlikheidstruktuur ingetrek word, kan die kommunikatiewe driehoek in die homiletiese proses soos volg versteur word (kyk Figuur 4).

Die kommunikatiewe struktuur in die bostaande visuele voorstelling kan soos volg verduidelik word. Die prediker verhef hom- of haarself (onbewustelik) tot die middelpunt van die homiletiese proses. Selfgesentreerde motiewe, vrese en die gekleurde lens van sy of haar eie lewensbeskouing kan 'n baie groter rol speel as wat die prediker ooit kon dink. Die prediker kan magsverskuiwinge in die kultuur waarin sy of haar lewe ingebed is, beskou as 'n bedreiging vir sy of haar gemaklike en onaantasbare posisie.

Die pre-okkupasie van die prediker met sy of haar eie persoonlike kwessies kan hom of haar onbewustelik op 'n selektiewe en manipulerende wyse met die teks laat omgaan.
Sy of haar eie interpretasie van die waarheid word via die teks voorgestel as die enigste en absolute waarheid. In die verhouding ten opsigte van die hoorders kan die prediker hom- of haarself op ' $n$ troon plaas en hulle manipulerend dwing om in 'n sekere rigting te beweeg en op ' $n$ wyse te dink wat pas by sy of haar voorkeure en sy of haar magsposisie verskans. Die prediker is so geposisioneer dat die hoorders nie in 'n lewende verhouding met die teks gebring word nie, maar slegs in 'n verhouding met die prediker se interpretasie van die teks.

\section{Pneumatologiese verankering van die kommunikatiewe driehoek in die verbondsruimte, waarin Jesus Christus, die gekruisigde en opgestane Here, versoenend (integrerend) teenwoordig is}

Na my oordeel het die maniere waarop die kommunikatiewe driehoek kan disintegreer en skeeftrek ten diepste te doen met 'n oppervlakkige visie rakende die aard van die verbintenis tussen teks, hoorders en prediker asook met 'n onvoldoende inagneming van die kragveld van die verbondsruimte waarin die betrokke kommunikatiewe proses veronderstel is om ingebed te wees. Wanneer bloot by die oppervlakte van die homiletiese proses gebly word, kan preekmaak in 'n meganiese, antroponome oefening ontaard waarin die aktiwiteite van eksegese, hermeneuse en homilese kategories en tegnies hanteer word en daar nie deurgaans rekening gehou word met die Goddelike teenwoordigheid en aktiwiteit tydens die proses nie. In 'n oppervlakkige homiletiese visie kan die lokus vir dit wat die Woordgebeure moet laat plaasvind, na die vermoë van die prediker verskuif word. Hy moet nuwe insig oopmaak deur die Skrif op 'n vaardige wyse eksegeties te ontsluit. Hy moet die Skrif beskerm teen aanpassing en verskraling. Hy

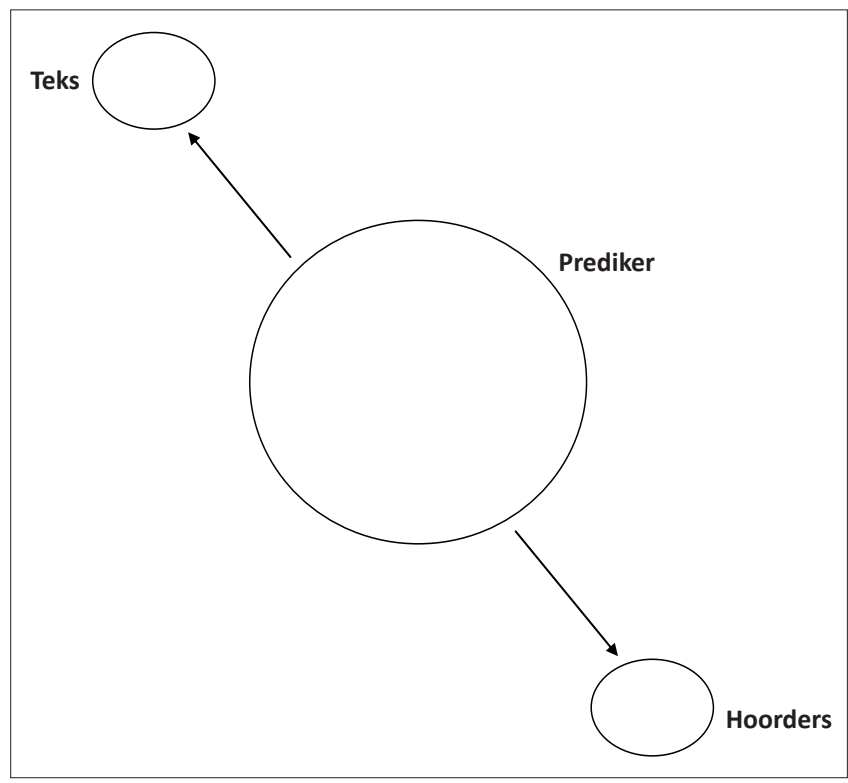

FIGUUR 4: Distorsie ten opsigte van die kommunikatiewe rol van die prediker. 
moet die hoorders deur homiletiese tegnieke aanklank by die Woord laat vind. Hy moet beheer van die situasie neem en gesag inboesem, anders - so lyk dit vir hom - sal alles in die kerk uitmekaar val. Wanneer die lokus vir effektiwiteit van die kommunikatiewe Woordgebeure na menslike vermoë van die prediker verskuif, kan aspekte soos vrese oor verlies aan eie magsposisie en selfverheffing onbewustelik disintegrasie en skeeftrekking tot gevolg hê.

Die waarnemer raak bewus van die kragveld van die verbondsruimte waarin die homiletiese proses veronderstel is om voltrek te word wanneer daar pneumatologies (onder leiding van die Gees van Christus) op dieptevlak van die homiletiese proses met die geestelike oë van die geloof gekyk word. Met 'verbondsruimte' word verwys na die lewensruimte en invloedsfeer waarin die verhoudingsnetwerk waarmee God sy verbondsmense aan Hom en aan mekaar verbind, geaktiveer word. In die Bybelse inkleding van die verbondsruimte word kommunikatiewe netwerke gekenmerk deur toewyding en trou aan verbondsgenote. In die pad wat God met Abraham, die vader van die gelowiges, loop, word dit by wyse van verbondsluiting duidelik gemaak dat God Hom op 'n blywende wyse aan sy mense wil verbind (Gen 15; 17). Hy wil vir hulle 'n God wees en aan hulle 'n seënryke lewe in gemeenskap met Hom gee (Gen 12:1-3). Hy wil 'n ewige verbond tot stand bring (Ps 108:8-11; 2 Sam 7:16, 29). Hy wil ook dat sy mense hulle gewillig en met hulle hele wese aan Hom verbind. Die oorvloedige liefde van God kan nie op 'n ander manier deur sy mense begroet word nie, as met ' $n$ troue liefde waarin die hele hart en siel en al die kragte uitgestort is (Deut 6:4; Jer 50:4-5). Ten einde die wedersydse verhouding tussen teonome en antroponome elemente in die verbondsverhouding nader te omlyn, kan gestel word dat die verbond 'n monopleuriese struktuur kragtens die ontstaan daarvan het, terwyl 'n dupleuriese struktuur in die werking daarvan na vore tree (vgl. Vorster 2007:195; Van Pelt 1999:278). Die verbond is monopleuries kragtens die ontstaan daarvan. Dit is God self wat die eerste tree gee en mense roep om in 'n verbond met Hom te staan. Dit is Hy en Hy alleen wat die ruimte kan oopmaak om die ewige, onverbreekbare verbond wat $\mathrm{Hy}$ in die oog het, te kan laat realiseer. Die verbond is egter dupleuries in die werking daarvan. Met laasgenoemde tipering word nie die gelykheid of gelykwaardigheid van die verbondsgenote bedoel nie, maar word aangedui dat die verbond bestem is om in die krag van God bewustelik, sonder aarseling en sonder dwang deur die mens aanvaar te word (Van Pelt 1999:279). Kragte soos manipulasie, magsvergryp, wantroue, vervreemding en verdeelde belange getuig van sondige verskeurdheid en is wesenlik in stryd met die aard van God se verbond met sy mense.

In die ruimte van die verbond, waarvan Jesus Christus die Middelaar is, is 'n aantrekkende kragveld aan die werk waarin al die faktore wat die prediker in sy verhouding met die teks, hoorders en homself in ontrou of vervreemding kon laat verval, deur Goddelike aktiwiteit deurbreek.
Volgens Lischer (2002:269) het God ons apistia oorkom deur 'n dramatiese nuwe handeling van pistis - pistis van Jesus Christus wat deur God gegee is as 'n duidelike demonstrasie van God se eie getrouheid aan sy verbond (vgl. Rom 3:21-25). Ons verhouding van vertroue in en toewyding aan God word herstel deur geloof in die volmaakte verlossing wat deur Jesus Christus vir ons bewerk is. In Christus Jesus word die kragte wat ons aan God en mekaar verbind en ons in staat stel om 'n lewende getuienis van hoe lieflik dit is waar God regeer aan die wêreld uit te straal, veel oorvloediger as die kragte wat ons van God en mekaar kan skei en vervreem. In Jesus Christus, die Gekruisigde en opgestane Here, word die disintegrerende kragte van die dood (ook die dood van 'n verhoudingsnetwerk) deur die integrerende krag van die lewe, oorwin (vgl. Rom 5:15-17).

Die verhouding tussen teks, hoorders en prediker kan soos volg gevisualiseer word, wanneer bewustelik rekening gehou word met die kragveld van die verbond soos dit deur die teenwoordigheid van die gekruisigde en opgestane Jesus Christus in ons midde geaktiveer word (kyk Figuur 5).

Vanuit die invalshoek van die prediker se betrokkenheid in die homiletiese proses kan daar in die kragveld van die verbond getrou gebly word aan die teks, aan die hoorder en aan hom- of haarself. Getrou aan die teks: Die enigste gepaste verhouding met 'n teks waarin God aan die woord kom, sou wees om toe te laat dat die eie inperkende denkkonstruksies en halfhartigheid weggesmelt word en die hart vervul word met heilige ywer en oorvloedige vreugde in die volheid van verbondslewe wat deur die Here in sy Woord geopenbaar word.

Getrou aan die hoorders: Kragtens die pneumatologiese bepaaldheid deur die boodskap van die kruis wat verkondig word, sou die dimensie van betrokkenheid by die hoorders en hulle ervaringswêreld 'n gestalte aanneem waarin alle terughoudendheid, skynbetrokkenheid en kunsmatigheid deurbreek word. Jesus Christus het sy lewe

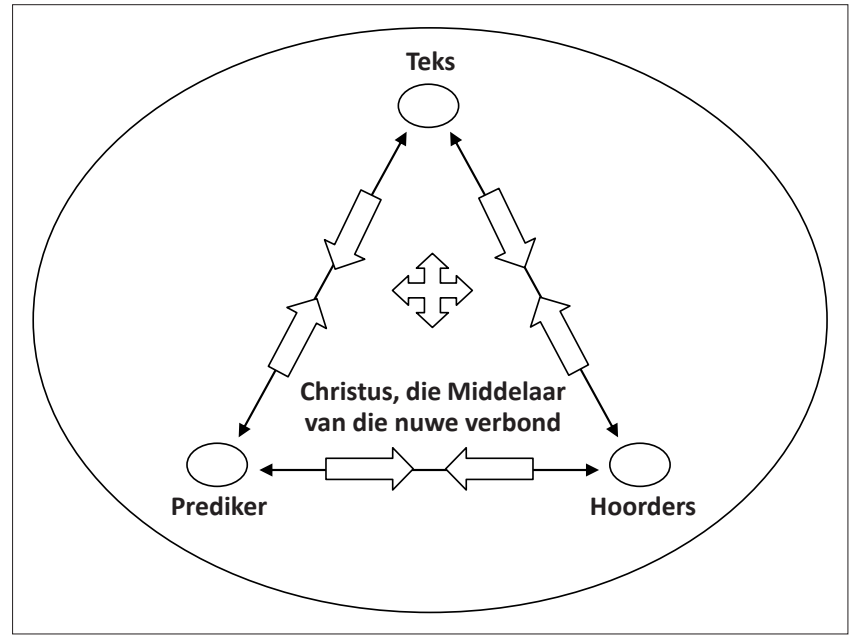

FIGUUR 5: Die plek van Jesus Christus as die Middelaar van die nuwe verbond in die kommunikatiewe driehoek. 
ten volle (sonder enige terughoudendheid) uitgegiet sodat 'n onbevange stroom van lewe kan vloei vir gelowiges wat reeds in 'n verbondsverhouding met Hom staan, sowel as vir diegene wat geroep word om in Hom te glo en tot die verbondsverhouding toe te tree. Volle oorgawe in gerigtheid op die mededeelgenote in die genade van God is die kenmerkende kommunikatiewe struktuur wat in die kragveld van die verbond na vore kom.

Getrou aan hom- of haarself (as mens wat na die beeld van Christus vernuwe is): In Christus Jesus word ons menslikheid

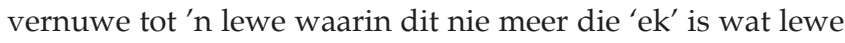
nie, maar Christus wat in my lewe. Die prediker hoef homof haarself nie langer onder die ondraaglike druk te plaas om in eie krag 'n kunsmatige ruimte vir geloofwaardige kommunikasie te skep nie. Hy of sy verkeer in 'n ruimte waarin hyof sy tot die besef kom dat krag van die Here juis tot volle werking kom wanneer hy of sy swak is (2 Kor 12:9).

\section{Slot}

Die gevolgtrekking waartoe in hierdie artikel gekom word, is dat die prediker in die kragveld van die verbond in staat gestel word om getrou te bly aan die teks (waarin God aan die Woord kom), aan die hoorders (in gerigtheid op mededeelgenote in die genade van God sowel as - in missionêre konteks - in gerigtheid op mense wat geroep word om mededeelgenote in die genade van God te word) en aan hom- of haarself (as nuwe mens in Christus). Dit word gedoen sonder dat die verbintenis aan een element in die kommunikatiewe driehoek die verbintenis aan die ander versteur of disintegreer.

\section{Erkenning Mededingende belange}

Die outeur verklaar dat hy geen finansiële of persoonlike verbintenis het met enige party wat hom nadelig kon beïnvloed in die skryf van hierdie artikel nie.

\section{Literatuurverwysings}

Andriessen, H.C.I. \& Miethner, R., 1993, Praxis der Supervision, Beispiel: Pastorale Supervision, Asanger, Heidelberg.

Bakker, H., 2007, 'Dichtbij, dichter bij, nog dichter bij', in W. Dekker \& J. Douma (reds.) Dichtbij de hoorder-prediking en trends, pp. 25-44, Kok, Kampen.

Bowen, M., 1978, Family Therapy in Clinical Practice, J. Aranson, New York.

Brueggemann, W., 2005, 'The Preacher, the Text and the People', Review and Expositor, 102(Summer), 493-506.

Brueggemann, W., 2010, The Word militant: Preaching a decentering word, Augsburg Fortress, Minneapolis.

Cilliers, J.H., 2009, 'Skrifbeskouing en oorredingsretoriek: Perspektiewe op performatiewe prediking', Acta Theologica 2009(1), 1-16.

Coetzee, J.C., 1985, 'Drie wesenlike elemente van egte prediking - Indikatief, Imperatief en Belofte', in J. Van der Walt (red.), God aan die Woord, pp. 17-28, Departement Diakoniologie, Potchefstroom

De Wet, F.W. \& Kruger, F.P., 2010, “n Prakties-teologiese perspektief op die handeling van kerklike besluitneming: Praktykteorie', In die Skriflig 44(2), 405-427.

Dingemans, G.D.J., 1991, Als hoorder onder de hoorders: Een hermeneutische homiletiek, Kok, Kampen.

Douma, J., 2000, Veni Creator Spiritus, De meditatie en het preekproses, Kok, Kampen.

Frör, K., 1961, Biblische Hermeneutik-zur Schriftauslegung in Predigt und Unterricht, Kaiser, München.

Gadamer, H-G., 1979, Truth and Method, transl. W. Glen-Doepel, Sheed \& Ward, London.

Guerin, P.J., 1996, Working with relationship triangles: The one-two-three of psychotherapy, Guilford Press, New York.

Heymel, M., 2006, 'Predigen - die schwierigste aller Künste Anstöße von Sören Kierkegaard für die heutige Homiletik', International Journal of Practical Theology 10(1), 34-52. http://dx.doi.org/10.1515/IJPT.2006.005

Lischer, R., 2002, The company of preachers: Wisdom on preaching, Augustine to present, Eerdmans, Grand Rapids.

Monshau, M., 2006, Preaching at the double feast: Homiletics for eucharistic worship, Liturgical Press, Collegeville.

Pieterse, H.J.C., 2010, 'Die dialektiek tussen leser en teks: 'n Gesprek oor hermeneutiese homiletiek', Verbum et Ecclesia 31(1), 1-6. http://dx.doi. org/10.4102/ve.v31i1.391

Runia, K., 1983, The sermon under attack Paternoster, Exeter. (The Moore College Lectures).

Stott, J.R.W., 1992, The contemporary Christian-Applying God's Word to today's world, InterVarsity Press, Downers Grove.

Tisdale, L.T., 2010, Prophetic preaching: A pastoral approach, Westminister John Knox Press, Louisville.

Van Leeuwen, T. \& Struijs, T., 2008, 'Preekbespreking of predikantsbespreking? Als een leerling leren preken- Preekvoorbereiding stapsgewijs, pp. 144-154, Boekencentrum, Zoetermeer.

Van Pelt, J.W., 1999, Pastoraat in trinitarisch perspectief - De samehang van trinitarische en antropologische aspecten in het pastoraat, Uitgeverij Groen, Heerenveen.

Vorster, J.M., 2007, Christian attitude in the South African liberal democracy, Potchefstroom Theological Publications, Potchefstroom.

Vorster, J.M., 2010, "n Ekklesiologiese model vir die bediening van versoening in ' $n$ sosio-politieke konteks', In die Skriflig 44(2), 429-454.

Vos, C.J.A., 1995, Die blye tyding - Homiletiek uit 'n hermeneuties-kommunikatiewe perspektief, RGN, Pretoria. 